\title{
Konaklama İşletmelerinde Kadınlara Özel Katlar
}

\author{
Faruk Alaeddinoğlua ${ }^{a^{*}}$ Avşin Ayhan ${ }^{b}$ \\ aVan Yüzüncü Yal Üniversitesi, Edebiyat Fakültesi, Van. \\ ${ }^{b}$ Van Yüzüncü Yıl Üniversitesi, TOIYY, Van.
}

\section{$\ddot{O} z$}

Turizmin dinamik yapısı ve yeni arayışlar destinasyonlar düzeyinde değişimi zorunlu hale getirmiştir. Bu yeni süreç birçok turizm alt sektöründe olduğu gibi konaklama işletmelerinde de kendini göstermiştir. Zira yaşanılan sosyo-kültürel ortam, gelir seviyesi, eğitim düzeyi ve cinsiyet gibi birçok değişken insanlar arasında farklılığa neden olmakta ve doğal olarak talepte de farklılıklar meydana gelmektedir. Bu bağlamda farklllık yaratan değişkenlerden biri olan cinsiyet, tüketicilerin konaklama işletmeleri seçimindeki karar alma süreçlerini etkilemekte ve konaklama tesislerinin tercih edilme sıklı̆̆ında cinsiyet giderek daha fazla önem arz etmektedir. Bu nedenle üzerinde araştırma yapılması gereken tüketici gruplarından birinin de kadınlar olduğu görülmektedir. Zira, her geçen gün değişen konaklama işletmeleri incelendiğinde, kadınlar için bir dizi yeniliğin yapıldığı anlaşılmaktadır. Bu değişikliklerden biri de kadınlara özel katların tahsis edilmesidir. Söz konusu konaklama işletmeleri kadın misafirleri için kadınsı oda tasarımları, dekorasyonlar, özel asansörler, güzellik-bakım aksesuar-malzemeleri ve kadın çalı̧̧anlar gibi birçok yeniliği hayata geçirmişlerdir. Bu çalışmada, farklı ülkelerde gelişmekte olan kadınlara özel katlar velveya oteller incelenmiştir. Çalışmada, kadın temalı konaklama işletmelerinin sayıca artması, bu tesislere yönelik talebin düzeyi, bu otellerin tercih edilme nedenleri gibi sorulara cevaplar aranmış ve ampirik çalıșmadan elde edilen sonuçlar ortaya konulmuștur. Kadınlara özel katlar konseptinin temelde iki değişkenle ilgili olduğu tespit edilmiştir. Bunlardan ilki, kadınlarm seyahatleri strasında kendilerini güvende hissetmeleri, diğeri ise kadınlarm kendilerini özel hissetme ve gerçekleştirme eğiliminde olmalarıdır. Bu durum kişisel tercihe bağhl olarak gelişen bu konseptin ayrımcılık temeline dayanmadığının açık bir göstergesidir. Ayrıca, çalışmada farklı görüş ve yaklaşımlara yer verilmek suretiyle konu derinlemesine analiz edilmiştir.

Anahtar Sözcükler: Kadın Turistler, Özel İlgi Turizmi, Niş Pazar, Konaklama İşletmeleri

\section{Women-Friendly Floors in Hospitality Industry}

\begin{abstract}
The dynamic structure of tourism and new searches has made changes in the level of destinations mandatory. This new process has emerged in the hospitality business as in many tourism sub-sectors. As the socio-cultural environment, income level, education level and gender are causing the difference between many people, they also cause the differences in their demands. In this context, gender, which is one of the variables that make a difference, affects the decision making processes of consumers choosing their accommodation, and the gender factor is increasingly important in the manner and frequency of choosing accommodation facilities. Therefore, it can be said that one of the consumer groups that need to be researched is women. It is observed that a number of innovations in the accommodation establishments have started to be made for women and they are changing every day. One of these changes is the allocation of special floors for women. These accommodation establishments have implemented many innovations such as feminine room designs, decorations, special elevators, beauty-care accessories and materials and female employees for their female guests on those floors. In this study, we examined the trend of special floors and/or hotels for women that are developing in different countries of the world. In the
\end{abstract}

*Yazışma adresi. Email: falaeddinoglu@hotmail.com 
study, areas of research such as the increase in the number of women-themed accommodation establishments, the level of demand for these facilities, the reasons of the preference of these hotels were searched and the results obtained from the empirical study were demonstrated. It has been understood that the concept of women-specific floors is basically related to two variables. The first is that women feel safe during their travels, and the other one is that they tend to feel special and perform better. This is a clear indication that this concept, which is developed on the basis of personal preference, is not based on discrimination. In addition, the subject was analyzed in depth with different views and approaches.

Keywords: Women Tourists, Special Interest Tourism, Niche Market, Accommodation Establishment

\section{GİRIŞ}

İnsanlık tarihi boyunca sosyal, ekonomik ve kültürel yaşamın içinde aktif olarak yer almış olan kadınlar belirli dönemlerde yaşamın kendisi ve yaratılan düzenin bizzat belirleyicisi olmuşlardır. Zaman ve mekân farklılaşmaları kadınlara yüklenen anlamı değiştirse de dünya tarihinde kadınlar hep karar verme mekanizmalarının içinde yer almışlardır. Ancak tarihin her döneminde kadınlar toplumsal dinamikler içerisinde yerlerini ve statülerini kazanmak ve onu korumak için çok daha fazla çaba harcamak zorunda kalmışlardır. Bilişim ve bilgi toplumunun yarattı̆̆ı yeni dünyada, sahip oldukları sosyal zeka sayesinde kadınlar, daha çok varlıklarını hissettirmeye, haklarını daha güçlü bir şekilde talep etmeye ve taleplerini daha fazla dile getirmeye başlamışlardır. Kadın kimliği üzerinden yaratılan bu yeni talep ve beklentiler dünyanın birçok ülkesinde karşılık bulmuş ve en katı rejimlerde dahi bu yaklaşım kendini çoğaltmaya başlamıştır.

Geçmişten günümüze kadının toplumdaki yeri ile ilgili toplumsal cinsiyet kavramı üzerinden yaşanan gelişmeler kadın odaklı birçok çalışmanın gerçekleşmesini sağlamıştır. Bu bağlamda tüketici davranışı araştırmalarında da en çok üzerinde durulan faktörlerden birinin cinsiyet olduğu anlaşılmaktadır (Kılıçer vd., 2016: 122).

Günümüzde kadınların ekonomik özgürlüğe sahip olmaları onlara satın alma gücü sağlamaktadır. Bu güç aile için yapılan harcamaların yanı sıra kadınlara kendileri için de satın alma imkânı sunmaktadır (Özdemir ve Tokol, 2008: 57). Kadınların çalışma hayatına katılması, kadına karşı toplumsal algının değişmesi ile birlikte satın alma alışkanlıklarında da farklılıklar görülmeye başlanmıştır. Örneğin, erkekle ilgili olduğuna inanılan prezervatif gibi cinsellikle alakalı ürünler, oto ve tamirat malzemeleri kadınlar tarafından da satın alınabilmektedir (Tekvar, 2016: 1603). Bu satın alma alışkanlıklarının esasında erkeklere özgü olduğunun düşünüldüğü zamanların ötesine geçen kadınlar günümüzde aynı satın alma davranışlarını gösterebilmektedirler. Barletta, "Kadınlara Pazarlama" adlı kitabında erkeklerle kadınlar arasında satın alma davranışı arasındaki farklılıklara dikkati çekmiş ve farklı cinsiyetteki tüketiciler arasındaki temel ayırıcılardan bir tanesinin, kadınların satın alma kararı verirken aradıkları ürünün diğer ürünlerden farklı olmasını önemsedikleri sonucuna ulaşmıştır (Barleta'dan akt. Albar, 2011: 84). Bu farklılık beklentisinden yola çıkılarak kadınlar odaklı pazarlama araştırmaları üzerinde durulmuştur. Buna ek olarak kadınlar genetik yapısı açısından olduğu kadar dikkat ve odaklanma, detaylı 
düşünme gibi düşünsel yönlerden de erkeklerden farklıdırlar ve bu farklılıklar cinsiyet anlamında farklı tüketici davranışlarının ortaya çıkmasına neden olmaktadır (Özdemir ve Tokol, 2008: 57).

Günümüzde kadınların çalışma ve sosyal hayatta daha fazla yer almasıyla birlikte kadınlar yeniliklere, öğrenmeye ve denemeye açı, kendisine sunulan fırsatların farkında olan, bilinçli bir tüketici kimliği kazanmışlardır (Koca ve Çağman, 2012: 161). Aynı zamanda kadına karşı değişen toplumsal algı, kadının kendi benliğinin farkına varması bilinçli bir kadın tüketici kuşağının oluşmasına neden olmaktadır. Bu durum, diğer sektörlerde olduğu gibi konaklama sektöründe de kadınların satın alma davranışlarında farklılıklara sebep olmuştur. Bu farklılığı gören işletmeler kadınlara kendilerini özel hissetmeleri adına jestler yapmaya başlamışlardır. Yalnız kalma, güvende olma isteklerini yerine getirmek ve diğer birçok imkânı sağlamak adına işletmeler yeni konseptlere yönelmişlerdir.

Konaklama sektörü insanların kişisel talep ve beklentilerine önem veren bir sektör olduğundan, yeniliklere de açıktır. Kitlelere, topluluklara veya kişilere kendilerini özel hissettirmek hizmet sektörünün altın kuralıdır. Bu kuralları yakından takip eden ve başarılı olmak isteyen işletmeler günümüz trendlerini de oldukça yakından takip etmektedirler. Bu nedenle kadınların toplumun temel taşlarından biri olduğu gerçeğinden hareketle kadınlara kendilerini özel hissettirmek için kadınlara özel katlar konsepti konaklama işletmelerinin yeni trendleri arasında yerini almaya başlamıştır. Her geçen gün artış gösteren bu trend aynı zamanda dünyada farklılıklara saygının da arttığının bir göstergesidir. Kişisel zevk ve isteklere saygılı olmanın yolu aynı zamanda farklılıklara saygı göstermekten geçmektedir. Dolayısıyla bu konsept kişilerin birbirinden soyutlanarak yaşamasından ziyade, tercihlerine saygı duymak üzerine geliştirilen bir konsepttir. Kişilerin cinsel yöneliminden yaşam tarzına ve konforuna kadar tüm detaylara önem veren bu konsept tamamen tercihe dayalı olup zorlayıcı bir temele dayanmamaktadır. Kadınlar bu konsepti, kendilerini daha rahat, daha güvende hissetme düşüncesi yanında merak duygusuyla da bu katları deneyimlemek istemektedirler. Bu fikrin zorlayıcı bir altyapısının olmaması taleplerin hizla artmasina neden olmaktadır.

$\mathrm{Bu}$ çalışmada, konaklama işletmelerinin kadınlara özel kat oluşturmaları ele alınmıştır. Bu bağlamda çalışmada dünyanın farklı ülkelerinde faaliyet gösteren bazı otellerin başlatmış olduğu kadınlara özel katlar trendi, bu otellerin dünyadaki dağılımı, kadınlar tarafından tercih edilme nedenleri, bu katların doluluk oranı, kadınların ve işletmelerin bu konudaki görüşleri incelenmiştir. Türkiye'de uygulanabilme potansiyeli olan bu konsept, yerli veya yabancı kadın turistlere seyahat rahatlığ1 sağlamanın yanında ülke turizmine katkı sunabilecek nitelikte bir alternatif yaklaşım içermektedir. Özellikle iş ve ticarete konu olan kentler açısından uygulanabilir bir konsepttir. Kitlesel bir yoğunlukla sürekli tüketim amaçlı seyahat eden turist profilinden kısmen de olsa farklılık gösteren, kendi kişisel istek ve beklentilerinin farkında olan, farklılıklara saygılı, bilinçli bir turist profilini içeren bir konsept olan bu yaklaşım, küçük ölçekli olsa da hızla çoğalmaktadır. 


\section{TOPLUMSAL CINSİYET EŞİTSİZLIĞ́̇ BAĞLAMINDA GEÇMISSTTEN GÜNÜMÜZE KADIN}

Tarihsel süreç içerisinde kadının toplumsal konumu irdelendiğinde üç önemli dönemin olduğu anlaşılmaktadır. Bunlar; toplayıcılık ile avcılığın temel ekonomik belirleyici olduğu birinci dönem, tarımın egemen olduğu ikinci dönem ve sanayinin ortaya çıkışı ve yaşanan devrimle birlikte gerçekleşen üçüncü dönemdir (Ata, 2010: 18). Ancak; kadın mücadelesinde yaşanan asıl kırılmanın 19. Yüzyılda Batı'da yaşanan ekonomik ve politik gelişmeler olduğu kabul edilmektedir. Bu gelişmeleri şu şekilde sıralamak mümkündür. Bunlardan ilki, 19. yüzyıl öncesinde Avrupa'da gelişen kapitalist üretim şekli, ikincisi, 18. yüzyılın sonlarında meydana gelen Sanayi Devriminin toplumsal yapı ve toplumsal ilişkileri derin bir biçimde etkilemiş olması ve fabrikalarda yeni bir üretim biçiminin doğması, üçüncü olarak da, fabrika sayılarındaki artışla birlikte kadınların gelir getiren iş yaşamına dâhil edilmeleri ve yalnızca ev içinde onlara tanımlanan görevlerin dişına çıkmış olmaları şeklinde siralanabilir (Karaslan, 2015: 1).

Kadınların cinsiyet eşitsizliğine uğradıklarını anlamaları ise; kamusal ve özel alanın çerçevesini net olarak çizen aydınlanma fikirlerine dayanan batıya dayalı modernleşmeyle beraber olmuştur. Ataerkil deyişler kadınları özel alana obje olarak konumlandırmış, kadınların yaşamlarını özel alan ile sınırlandırmıştır (Göl, 2010). Kadınların ev içerisine konumlandırılmış olması ötekileştirmenin başlangıç noktasını oluşturmaktadır. Bu bağlamda bir insanın kendisini "öteki” olarak tanımlama ihtiyacı duyduğu her yerde bir kimlik sorunu var demektir (Aktaş, 2013: 57). Buradan hareketle, kadın cinsiyeti için dünyanın en kalabalık nüfusuna sahip olan "öteki" demek mümkün olabilir (Alptekin, 2006: 1).

Kadınların sürekli maruz kaldıkları ayrımcılık kendilerine tanımlanmış olan bu kimlikler nedeniyledir. Kadınları belirli kalıplarla sınırlayan, toplum tarafindan belirlenen roller özgürleşmenin önündeki en büyük engeldir. Kadın ve erkek olmak biyolojik bir durumken, kadınların sosyal kimliklerinin tanımlanmasında etkili olan bazı değişkenler cinsiyetler arası ayrımcılığa neden olmaktadır. Bu değişkenler; sahip olunan ekonomik, kültürel, sosyal ve eğitimsel durum vb etmenlerdir. Bu etmenler sonucunda kadınlara belli roller biçilmekte ve bu rollerin dışına çıkılamamaktadır.

Kadınlar kendilerine tanımlanmış olan bu rolleri doğuştan elde etmez, toplum tarafından kendisine tanımlanan kodlara göre şekil alır. Annelik duygusu, kadınlar ev yemeklerini daha iyi yapar, evi temizlemek kadının görevidir gibi söylemler, kadınlara sonradan kültür veya toplum aracılığıyla dayatılan sorumluluklardır.

Kendisine tanımlanan görevlerin dişına çıkan kadınlar toplumda ayrımcılığa maruz kalmışlardır. Bu ayrımcılık kırsal alanda kadının yalnızca ev yaşamında rol alması gerektiği inancına dayanabilirken, kentte ise kadının var olmaya başladığı her alanda görülebilmektedir. Yaşanan bu ayrımcılıklar ortaya toplumsal cinsiyet eşitsizliği kavramı çıkmıştır. UNESCO'ya (Birleşmiş Milletler Eğitim, Bilim ve Kültür Örgütü) göre, toplumsal cinsiyet eşitliği; kadın ve erkeklerin, toplumsal cinsiyet eşitliği gereğince eşit haklara ve fırsatlara sahip olmasıdır (UNESCO'dan akt. Karaslan, 2015: 
5). Bu tanımlamaya ters düşecek şekilde kadınların uğradıkları hak ihlalleri toplumsal cinsiyet eşitsizliği olarak ifade edilebilir.

Gelişmemiş toplumlarda kadınlar hala bu ayrımcılığın öznesidirler. $\mathrm{Bu}$ ayrımcılık geçmişte daha belirginken günümüzde biraz daha azalmıştır."Bir genelleme yapılacak olursa günümüzde, kadın haklarının ya da kadının özgürlüğünün geçmiş yaşanmışlıklara göre altın çağını yaşadığı iddia edilebilir (Yayla, 2010).

Kadının sosyal ve iş yaşantısında gerçekleştirilen iyileştirmeler kadın-erkek eşitliği konusunda oldukça önemli adımlar atılmasına neden olmuştur. Avrupa Birliği'nin kadın-erkek eşitliği odaklı çalışmalarında şu konulara yer verilmektedir (Arısoy ve Demir, 2007'den akt. Çakır, 2010):

- Karar alma organlarında cinsiyetler arası dengenin sağlanması,

- İş ve ev hayatının birlikte yürütülebilmesinin kolaylaştırılması,

- Kadınların bilim dünyasına yer almasının desteklenmesi,

- Kadınların şiddet ve cinsel tacize maruz kalmasının önüne geçilmesi,

- Kadınlara yönelik genel eğitim ve mesleki eğitim imkânlarının maksimize edilmesi,

- Eşit işe, eşit ücret uygulamasının yaygın hale getirilmesi,

- Kadınların iş yaşamında varlığının arttırılması.

Büyük mücadeleler sonucunda gelinen bu durum göz önüne alındığında; günümüzde yukarıdaki maddelerin hemen hemen hepsinin kadınların hayatına bir biçimde etki ettiği görülmektedir. Simon de Beauvoir'ın "Kadın, toplumsal açıdan üretime daha çok katılıp ev işleriyle daha az uğraştığı zaman özgürlüğe kavuşacaktır" cümlesi günümüz dünyasında kabul görmeye başlamıştır.

Kadınların sosyal ve ekonomik yaşantısındaki değişimler kadını kendisine tanımlanan kimliklerden kurtarıp, insan sosyal bir varlıktır düşüncesinin merkezine taşımıştır. Kadınlarla ilgili değişen kalıp yargılar tüketici satın alma davranışlarında cinsiyet kavramına daha çok odaklanmayı da beraberinde getirmiştir.

Kadın ve erkeklerin farklı talep ve beklentileri konaklama işletmelerini cinsiyete dayalı farklılaşmaya yöneltmiştir. Bu bağlamda kadını odak noktasına koyan yeni konaklama trendleri ortaya çıkmıştır.

\section{LITTERATÜR}

\subsection{Geçmişten Günümüze Kadınlara Özel Katlar Konsepti}

Kadın kimliğine uygulanan ayrımcılık uygarlık tarihinin her döneminde bir şekilde kendini göstermiştir. Kadınlar dünyanın birçok yerinde yıllar boyunca sömürüye, şiddete, ötekileştirilmeye, taciz ve tecavüze maruz kalmışlardır. Yalnızca özel yaşama ait bir canlı olarak tanımlanan kadının kamusal ve sosyal alandaki varlığı bir utanç vesilesi olarak görülmüştür.

Yakın zamana kadar kadının rolü evine, eşine ve çocuklarına hizmet etmek olarak tanımlanmaktaydı. Kadınların doğuştan gelen haklarını savunmaya başlamaları, diğer bir ifadeyle başkaldırıları yavaş ta olsa sosyal ve ekonomik hayatta 
yer almaya başlamalarına neden olmuştur. Örneğin, Yirminci yüzyılın ortalarına kadar Asya'da tatil erkekler ve üst sınıf kadınlar için bir ayrıcalık iken, günümüzde kadın seyahatlerine yönelik yeni pazarların oluştuğu anlaşılmaktadır (Harris ve Little, 2003'dan akt. Yang ve Hitchcock, 2016).

Kadınların çalışma hayatında yer almaya başlamasıyla ortaya çıkan seyahat etme durumu şehir dışında konaklama ihtiyacını doğurmuştur. Bu durumu otel ve franchise danışmanı Stanley Turkel şu şekilde açılamaktadır: "1900'lerde otel yöneticileri tek başına seyahat eden kadınları risk olarak görüyorlardı. Bu nedenle otellere utanç ve cazibe getireceklerinden korkularak kadınlara özel oteller kurulmuştur ve 1903'de açılan Martha Washington Hotel bu bağlamda yalnızca kadınlar için hizmet veren ilk otel olmuştur. Kadınların daha fazla seyahat etmeye başlaması ile birlikte oteller kadınlar ve çocuklar için özel katlar oluşturmaya başlamıştır. 1912'de açılan New York'taki McAlpin Hotel, kadınlara özel katlara, bu katlarda çocuklar için oyun alanlarına ve kadın kuaförlerine yer vermiştir (hotelnewsnow.com)." Böylece kadınlar kendilerini daha özel hissetmiş, çocuklar için oyun alanlarının oluşturulması özellikle çalışan kadınların odalarında daha rahat çalışabilmesinin yolunu açmış ve süreci desteklemiştir.

Başlangıçta kadınlar utanç kaynağı, cinsel obje, vasıfsız olarak görülmüş ve o ölçüde konaklama imkânlarından faydalanmışlar iken zamanla bu yaklaşım değişmiş ve kadınla erkeğin bir birinden ayrıştığı bir yapıya dönüşmüştür. Bu düşünce sonraki yıllarda seyahat eden kadın sayısının artmasına ve bu pazarın genişlemesine neden olmuştur. Bununla birlikte kadınlara özel katlar konseptinin her yerde başarılı olduğunu söylemek mümkün değildir. İlgili literatür incelendiğinde; konsepti uygulayan ancak başarılı olamayan otellerin olduğu da görülmektedir. Örneğin Marriot zincirinin 2007 yılında planladığı ve genel olarak ABD basını tarafından desteklenen Michigan'daki JW Marriot Grand Rapids'in bir katının yalnızca kadınlara özel olarak hazırlanması fikri, bir kısım kadın hakları savunucusunun öfkesine ve özellikle Los Angeles'ın ünlü ayrımcılık avukatı Gloria Allred tarafından büyük eleştirilere maruz kalmıştır. Yaşanan bütün bu olaylar üzerine otel kadınlara özel kat planından vazgeçmiştir (Minnaert, 2007).

Başarısız örneklere rağmen kadınlara özel katlar ve/veya oteller son yıllarda yeniden yaygınlaşmaya başlamıştır. Ancak bu yeni süreçle birlikte söz konusu katlar geçmişteki amaçlarından farklı olarak, seyahat eden kadınlar için güvenli bir ortam sağlamayı amaçlamaktadır (Finney, 2008). Zira dünyanın hemen her yerinde kadınlar doğrudan ya da dolaylı olarak şiddete ve tacize maruz kalmaktadırlar. Bazı ülkelerde kadınlara karşı taciz, şiddet ve tecavüz suçları için caydırıcı cezaların olmayışı bu suçları teşvik ederken, bu suçlarla caydırıcı bir biçimde mücadele edilen ülkelerde dahi bu suçlara maruz kalmak mümkündür. Yani kadınlar dünyanın hiçbir yerinde kendilerini tam anlamıyla güvende hissetmemektedirler.

21. Yüzyıl'da yalnız başına seyahat eden kadınların bulunduğunu ve her geçen gün sayılarının arttığını ve bu pazarın varlığını devam ettirdiğini söyleyen Euromonitor International'ın seyahat ve turizm endüstrisi araştırma yöneticisi 
Michelle Grant, bu pazarda artış gözlemlediklerini belirtmektedir (hotelnewsnow.com). Otellerde kadınlara özel katlar konsepti 2010 yılından bu yana New York, Londra, Berlin ve Toronto gibi büyük şehirlerde bir trend haline gelmiştir (arabnews.com).

Geçmişte ayrımcılık temelli olarak ortaya çıkan bu konsept, günümüzde kadının toplumdaki yeri dikkate alındığında yeni bir boyut kazanmıştır. Bu boyut kadının rahat seyahat etmesi, kendini güvende ve huzurlu hissetmesi temeline dayanmaktadır.

Dünyanın her yerinde bir ülkeden başka bir ülkeye yalnız başına seyahat eden kadınlar mevcuttur. Bir ülkeden bilmediği bir ülkeye seyahat eden bir kadın, güvenlik durumu hakkında pek fazla bilgisi olmadığından kendini daha güvende hissetmek adına bu konsepte sahip bir oteli tercih etmesi gayet anlaşılır bir şeydir.

\subsection{Kadınlara Özel Katlar Konseptinin Artmasının Nedenleri}

Günümüzde kadınların daha eğitimli olmaları, kadın hakları konusunda yapılan farkındalık çalışmaları, çalışma hayatında giderek artan kadın istihdamı ve yönetici pozisyonundaki kadınların sayıca artması gibi nedenler kadınların var olma ve kendilerini yaşadıkları topluma kabul ettirme süreçlerinde etkili olmuştur. Dolayısıyla kadınların hem kamusal hem de özel alandaki yerleri geçmişten günümüze oldukça fazla değişmiş ve olumluya doğru dönüşmüştür.

Günümüz kadınları gerek kamusal alanlarda gerekse iş hayatında aktif roller üstlenmektedirler. Bunun yanı sıra özel alanda faaliyet gösteren kadınlar giderek 'kendinin farkında olma' durumuyla karşı karşıyadır. Artarak devam eden bu durum, kadınların kendilerini daha özel hissetmelerinin yanında öz güvenlerinin de artmasına neden olmuştur.

Her geçen gün artış gösteren dinlence ihtiyacı da insanların kendilerini özel hissetmelerini sağlamak için uygun bir zemin hazırlamaktadır. Bu nedenle farklı motivasyona sahip olan turistlerin konaklama işletmelerinden beklentilerinin farklı olabileceği bir gerçektir (Çakıcı, 2000'dan akt. Harman, 2014, (Tannenbaum ve Schultz, 2011'dan akt. Karaaslan, 2015:8). Böylece, çalışan kadınların sayısında gözlemlenen artış turizm sektöründe kadınlar için özel çalışmalar yapılması ihtiyacını ortaya çıkarmıştır. Maiden Voyage Çalışan Kadınlar Seyahat Raporuna (2016) göre, hizmet sağlayıcıların \%70'i kadınların ihtiyaçlarını karşılamak için daha fazla çaba harcamaktadırlar. Ayrıca \%76,3'ü kadın yolcuların ihtiyaçlarına önem veren tedarikçilerle çalışmaları gerektiğine dikkat çekmişlerdir (sekkamag.com).

Kadın tüketicilerin farklı motivasyonları olduğundan hareketle konaklama işletmeleri bu durumu fırsata çevirmek için kadınlar için bir dizi yenilik yapmışlardır. Yapılan yenilikler bir yandan kadınsı dokunuşları içerirken, bir yandan da tamamen kadın merkezli radikal değişiklikleri kapsamaktadır. Kadınların bu katları tercih etmelerinin altında yatan en önemli neden, kadınların kendilerini özel hissetmelerinin verdiği duygusal doyumdur. Şüphesiz bireysel olarak seyahat eden kadınların sayıca artması globalleşen konaklama işletmelerinin de ilgisini çekmiş ve bu pazardan daha 
fazla pay almak için pazarlama çalışmalarına neden olmuştur. Dolayısıyla bu süreç, daha küçük, daha özel, daha incelikli fikirlerin üretilmesine vesile olmuştur.

Kadınların seyahat planlarında duygusal doyumdan sonra önem verdikleri bir diğer değişken de güvenliktir. Kişi kendisini güvende hissetmeyeceği bir yere seyahat etmek istemez. Dolayısıyla turistlerin risk algıları destinasyon seçiminde önemli bir faktördür. Araştırmalar, turistlerin risk algılarında kişilik özellikleri, milliyet, sosyal sınıf, cinsiyet, yaş gibi bir dizi bireysel faktörün etkili olduğunu göstermektedir (George, 2012' dan akt. Aksu ve diğerleri, 2013: 745). Araştırmalar korkunun kadınların seyahat alışkanlıklarında yönlendirici bir faktör olduğunu ortaya koymaktadır (Loukaitou Sideris, 2014). Kadınlar suça maruz kalma konusunda erkeklerden daha fazla endişelidirler (Gordon ve Riger, 1989). Dolayısıyla, özel katlar konseptinin gelişmesinin nedeninin kadınların güvenli bir seyahat geçirme istekleriyle doğrudan ilişkili olduğu söylenebilir. Örneğin; güvenlik sorunlarının sıkça yaşandığı Hindistan'da birçok otel markası kadınlara özel katlar konseptini benimsemiştir (smartertravel.com). Hindistan'da bulunan ITC Group otel zincirlerinin bazılarında kadınlara özel kat olan "Eva Floor" bulunmaktadır.

Cinsiyete bağlı olarak, güvenlik algısı destinasyon ve konaklama işletmesi seçiminde önemli bir yere sahiptir. Ayrıca risk algılama ve risk öncelikleme cinsiyet ve yaşa göre de farkl1lık göstermektedir (Carr, 2001'dan akt. Aksu ve diğerleri, 2013). Bu bağlamda kadınların riski algılama ve riske verdikleri önceliğin toplumsal cinsiyet algısıyla ilişkili olduğu söylenebilir. Birleşmiş Milletler'in Kadınlara Yönelik Şiddetin Yok Edilmesi bildirgesine göre; kadınlara uygulanan şiddet, sadece fiziksel güçten ibaret değil, aynı zamanda toplumsal cinsiyet temelli şiddet de kadınların fiziksel, cinsel ya da psikolojik olarak incinmelerine yol açabilmekte ve yaşamın her alanında gerçekleşebilmektedir (Karaslan, 2015: 19). Dolayısıyla cinsiyet, farklı risk ve güvenlik algilamalarında önemli bir belirleyicidir (Reisinger ve Mavondo, 2005'dan akt. Aksu ve diğerleri, 2013 ).

Kadınların güvenlik konusundaki bu hassasiyetinin farkında olan işletmeler, kadınların kendilerini daha güvende hissetmeleri için özel katlar konseptini kullanmaya başlamışlardır. Üst düzey güvenliğe sahip bu koridorlar otelin yanı sıra kendisini her anlamda güvende hissetmeleri adına kadınlar için önemli bir yeniliktir. Özellikle son yıllarda konaklama işletmelerinin satışlarını arttırabilmek için gerçekleştirdikleri bir dizi satış tutundurma uygulamaları vardır (Bakırtaş, 2013: 677). Güncel yenilikleri takip etmek konaklama işletmeleri için alternatif tutundurma yöntemleri sağlamaktadır. Kadınlara özel katlar konsepti de bu tutundurma uygulamalarından biridir.

Kişisel bir tercihe dayanan bu konsept seçimi, kadınların seyahat edecekleri yabancı bir ülke veya bölgede kendilerini daha güvende ve daha özel hissetmelerini sağlayacaktır. Dünya'nın birçok ülkesinde olduğu gibi Türkiye'de de kadınlara yönelik zaman zaman taciz, tecavüz, cinayet vb. olayları yaşanmaktadır. Bu konsept Türkiye'de seyahat etmek isteyen yerli kadın turistler için de alternatif olarak görülebilir. Kadınlar konaklayacakları oteli seçerken ekstra güvenlik isteyebilir ve bu 
konsept bu güvenliği sağlamada iyi bir alternatif olabilir. Bunun yanı sıra; kadınlara kendilerini özel hissettirmek ve bunu tamamen onların kendi tercihlerine birakmak seyahate olan talebi arttırabilir. Ayrıca bu konsept, kadınları ötekileştirmeden daha çok kadınları anlama temelli bir yaklaşımla farklılıklara saygılı bir sektör imajı yaratılmasına da katkı sağlayabilir.

\subsection{Kadınlara Özel Katlar Konseptinin İçeriği}

Cinsiyet, tüketimin olduğu her alanda, üzerinde sıklıkla durulan bir faktördür. Cornell Otelcilik Üniversitesinde görev yapan Profesör Judy Brownell'e göre, kadınların otel tercihleri erkeklerden çok farklıdır. Erkekler otel odasına girdiklerinde ilk olarak televizyonu açıp kontrol ederlerken, kadınlar banyonun güzel kokup kokmadığı, güzel bir küvete sahip olup olmadığ1 gibi detaylarla ilgilenmektedirler (edition.cnn.com). Bu bağlamda kadınlara özel katların sunduğu özellikler otelden otele detaysal farklılıklar gösterse de genellikle ekstra güvenlik hizmeti, kadınlar için özel olarak hazırlanmış çikolatalar, çiçekler veya kadınsal araç gereçler gibi hizmetleri içermektedir. Bu hizmetler daha yüksek bir fiyatlı bir otel odası anlamina gelmektedir (Minnaert, 2007).

Otelden otele değişmekle birlikte genel olarak bu konseptin içeriği şu şekilde sıralanabilir. Kadınlara özel katlar sunan, kadın dostu otellerden biri olan Le Meridien CEO'su Juergen Bartels: kadınların evlerinin tasarımını her geçen gün değiştirdiklerini ve geliştirdiklerini bu nedenle otellerin de kadınların bu eğilimlerini takip etmeleri gerektiğini ifade etmektedir (Swengley, 2003). Kadınların davranışsal değişimlerini takip etmek ve bunu otel odalarına yansıtmak, kadınlara seyahatleri sırasında ev konforu sağlarken aynı zamanda kendilerini özel hissetmelerine de imkan vermektedir.

İş için seyahat eden erkeklerin büyük ölçüde ortak kullanım alanlarında, kadınların ise odalarında çalışmayı tercih ettiklerini söyleyen Swengley, bu durumun farkında olan Marriot otellerinin daha geniş bir oda menüsü yaptırdığını ve bu durumun erkek müşteriler tarafından da memnuniyetle karşılandığını ifade etmektedir (Swengley, 2003).

Times Meydanı'ındaki In Millennium zinciri Premier Hotel, yoga matları, banyo tuzları ve SPA tarzı bir oda servisi içeren "Woman Travellers Floor" imkanı sunarken, Albany şehrindeki Hampton Inn, kadın konuklarına çerezler, aromalı kahveler, cilt nemlendiricileri, ekstra yumuşak çoraplar, otelin masaj koltuğunda yarım saatlik bir seans imkanı sunmaktadır (Finney, 2008). Otellerdeki kadın katlarına olan talebin artmasına paralel olarak, gerek tatil gerekse iş amacıyla seyahat eden kadınlar için, pek çok prestijli otel güvenlik ve konfora özel önem vererek yalnızca kadınlara özel katlara odaklanmaktadırlar (gulfnews.com).

Amerika kıtasında yer alan bu konsept oteller, genellikle lüks olarak adlandırılabilecek otellerdir. Amerika da zincir otel olan Crowne Plaza'aların bir kısmında bu konsepte yer verilmiştir. Avrupa'da ise genellikle zincir olan hosteller de görülen bu konsept, otellerde de bulunmaktadır. Asya kıtasında yer alan otellerde bu 
konseptin yer alma durumu ise ülkeden ülkeye derin farklılıklar göstermektedir. Örneğin Hindistan'da ve Dubai'de yer alan oteller genellikle beş yıldızlı ve zincir oteller şeklinde iken, Japonya da çoğunluğu tek yıldızlı olan kapsül oteller şeklinde faaliyet göstermektedirler.

Amerika kıtasında üç adet dört yıldızlı, iki adet üç yıldızlı; Avrupa kıtasında bir adet beş yıldızlı, iki adet dört yıldızlı, bir adet üç yıldızlı, on üç adet hostel; Asya kıtasında yirmi iki adet beş yıldızlı, iki adet dört yıldızlı, dört adet üç yıldızlı, sekiz adet iki yıldızlı, on beş adet tek yıldızlı kadınlara özel katlar konseptli konaklama tesisi bulunmaktadır. Kitalara göre kadınlara özel katlar konsepti bulunan oteller Tablo 1'de, bu özel katlarda sunulan hizmetler ise Tablo 2'de gösterilmektedir (Bkz Ekler).

Ekler kısmında Kitalar itibariyle Kadınlara Özel Katlar Bulunan Oteller Tablo 1'de ve Kadınlara Özel Katlar Konsepti Bulunan Oteller ve Sundukları Hizmetler (Özellikleri) Tablo 2'de verilmiştir.

\section{METODOLOJi}

Metropol kentler, turistik cazibe merkezleri ve ticaret merkezi özelliği olan kentlerde ağırlıklı olarak gelişen kadınlara özel katlar konsepti çalışmanın araştırma konusu olmuştur. Bu bağlamda araştırmaya farklı açılardan bakabilmek adına öncelikle bilimsel literatür incelenmiştir. Ancak konunun yeni olması ve yeterli literatürün olmayışı farklı arayışları beraberinde getirmiştir. Bu anlamda öncelikle, konaklama işletmelerinin konsepte ilişkin kendi web sayfalarında yayınlamış oldukları görüş ve düşünceler ile yazılı ve görsel medyada konunun tarafları arasında yapılan tartışma ve ifadelere (görüşlere) yer verilmiştir. Ayrıca konseptin tam olarak anlaşılabilmesi adına önceden hazırlanan görüşme soruları konunun tarafı olan konaklama işletmelerine mail yoluyla yöneltilmiştir. Kalitatif bir yöntemin benimsendiği bu araştırma Ekim 2017-Mayıs 2018 tarihleri arasında gerçekleştirilmiştir. Bu bağlamda Dünyanın farklı bölgelerinde faaliyet gösteren ve kadınlara özel katlar konsepti bulunan 67 işletme tespit edilmiş ve söz konusu otellerin bilgilerine ulaşılmıştır. Bu işletmelere kadınlara özel katlarla ilgili, on adet görüşme sorusu yöneltilmiştir. Otellerden altı (6) tanesi yöneltilen sorulara yazılı olarak cevap vermeyi kabul etmiştir. Ancak tespit edilen 67 otelin bir kısmının mail adresine ulaşılamamış ve dolayısıyla iletişim kurulamamıştır.

\section{Otellere yöneltilen sorular:}

1. Kadınlara özel katlar konseptinizin vizyonu ve misyonu hakkında kısaca bilgi verir misiniz?

2. Özellikle kadınlara özel katlar konseptini seçme nedeniniz nedir?

3. İşletmenizde konaklayan kadın misafirlerin, kadınlara özel katlar konseptine ilişkin memnuniyet düzeyleri nedir?

4. Kadınlara özel katlar konseptinde yalnızca kadın çalışanlar mı istihdam edilmektedir?

5. Kadın turistler işletmenizi kadınlara özel katlar konsepti nedeniyle mi ziyaret etmektedirler? 
6. Kadınlara özel katlar konsepti işletmenizin doluluk oranını ne oranda etkilemektedir?

7. Kadınlara özel katlar konsepti ile ilgili eleştiriler alıyor musunuz? Alıyorsanız nelerdir?

8. Kadınlara özel katlar konseptinizin LGBT hareketiyle bir bağlantısı var mıdır? Varsa nedir?

9. Kadınlara özel katlar konseptinizin feminizm hareketiyle bir bağlantısı var midir? Varsa nedir?

10. Kadın aktivistlerin kadınlara özel katlar konseptinize karşı tutumu nedir?

\section{OTEL YÖNETICIILERININ SORULARA VERDİKLERİ CEVAPLAR}

Kadınlara özel katlar konusunda hazırlanmış olan sorular e. posta yoluyla otellere yöneltilmiş ve verilen cevaplar büyük ölçüde olduğu şekliyle metne aktarılmıştır. Bu bağlamda otel yöneticilerinin sorulara verdikleri cevaplar kadınlara özel katlar konusunun daha anlaşılır olmasını sağlamıştır. Nitekim Ellis, Oberoi Otel Dubai ve Nadeshiko Otel bu durumu aşağıdaki şekilde özetlemektedir; Ellis Hotel Atlanta, "çalışan kadınlar rahat edebilecekleri yerleri arıyorlar ve kendilerine bunu hissettirebilecek bir yer yoktu. Bizde müşterilerin isteğini yerine getirmek için otelimizde bu konsepte yer verdik. Kadınlar bu odalar deneyimlemeyi, özel erişimi ve aktiviteleri seviyorlar. Kadınlara özel bu katta yalnızca kadın çalışanlar istihdam edilmemektedir. Kadınlara özel katlar konsepti otelin doluluk oranın çok iyi etkilemektedir. 2017'de kadınların tek katında 1200'den fazla oda rezervasyonu yaptık ve biz 127 odalı bir oteliz. Konseptle ilgili eleştiri almadık ve eleştiri alınacak bir durum olduğunu düşünmüyoruz. LGBT hareketiyle bir etkileşimimiz yoktur ve konseptimiz seyahat eden kadınlara yöneliktir. Ancak Feminizm hareketliyle bağlantımız vardır. Bu kat için Chelko Vakfi ile ortaklık kuruyoruz. Bu vakıf kar amacı gütmeyen, sanat yoluyla kadınların güçlenmesine adanmış bir vakıftır. Kadın aktivistlerin bu konsept ile ilgili tutumları hakkında bir fikrimiz yoktur. Biz yalnızca iş seyahati gerçekleştiren kadın müşterilerimizin beklentilerini karşıllyoruz".

Nadeshiko Otel Tokyo konseptimizin misyonu "farklı ülkelerden gelen turistlere yeni deneyimler kazandırmaktır. Otelimizin kadınlar tarafindan tercih edilme nedeni güvenliktir. Otelimizin konsepti nedeniyle kadın çalışanlar istihdam edilmektedir. Çalışanlarımızın \%90'ı kadınlardan oluşmaktadır. Kadınlar otelimizi yalnızca kadınlara hizmet verdiğinden dolayı ziyaret etmektedirler. Doluluk oranımızı etkilemektedir. Hafta sonları tamamen doluyuz. Konseptin LGBT hareketi ile bir bağlantısı yoktur. Otelimizde konaklamak için bazen trans bireylerden sorular alıyoruz ancak temel olarak, kişinin kimliği resmi olarak kadın olduğu zaman konaklamalarına müsaade edebiliyoruz."

Oberoi Otel Dubai, "kadınlara özel katlar konseptimizin vizyonu kadın gezginlerin mahremiyetinin ve konforunun en üst düzeyde olmasın să̆lamaktır. Misyonumuz mümkünse tüm kadın gezginlerin rezervasyonlarının bu kat'a yapılmasını sağlamak. Bu konsepti seçme nedenimiz kadın yolcuların sayısında gözlenen artış, kadınların mahremiyetine ve konforuna hitap edecek hizmetler şeklinde siralamak mümkündür. Kadınlar bu konseptin varliğından memnunlar. Kadınlara özel bu katta yalnızca kadın çalışanlar istihdam edilmektedir. Bir erkek çalışanın kat'a girmesi gerekiyorsa bir kadın çalışan eşlik etmektedir. Kadınlar konseptimiz 
nedeniyle otelimizi ziyaret eden misafir sayısında artıs gözlemlemekteyiz. Konsept doluluk oranın etkilemektedir. Bu nedenle otelimizi yeniden ziyaret eden kadın gezginler vardır. Kadınlara özel katlar konseptimiz ile ilgili bir eleştiri almadık. LGBT ve feminizm hareketi ile bir bağlantısı yoktur. Kadın aktivistlerin tutumlarına yönelik bir fikrimiz yoktur."

The Oberoi Bengaluru otelinin k1demli yöneticisi Pinky M. Padmaraj, konsept hakkında görüşlerini şu şekilde belirtmiştir:'bir zincir otel olarak, yalnız seyahat eden kadın gezginlerin güvenliği ve konforu konusunda bir takım hassasiyetlerimiz bulunmaktadır. Fakat bu süreç ve imkanlarla ilgili herhangi bir bilgiyi paylaşma özgürlüğümüz bulunmamaktadır. Bu nedenle görüşme sorularının detaylarına cevap verememekten ötürü üzgünüz."

The Oberoi, Bali'nin genel müdür'ü John Halpin konsept hakkında görüşlerini şu şekilde belirtmiştir: "tesisimiz tek katl, alçak gövdeli evlerden oluşmaktadır. Bu nedenle, sadece kadınlara özel bir kat olarak yer vermemiz mümkün değildir. Fakat bu yaklaşım Bali'de gereklidir. Otel olarak misafirlerimizin ihtiyaçlarına duyarlıyı. Yalnız seyahat eden kadınlar için odalarımıza hizmet götüren bütün çalışanlar kadınlardan oluşmaktadır. Yani oda temizliği görevlileri, konuklara odalarına kadar eşlik eden asistanlar v.b. kadın çalışanlardan oluşmaktadır".

The Oberoi Amarvilās'in müdür vekili Sanyam Saigal CHE konsept hakkında görüşlerini şu şekilde belirtmiştir. "Doğrudan kadınlara özel bir kat konseptine sahip değiliz. Fakat kadınlara özel asansörler, dergiler, özel bakım ürünleri gibi imkanlarımız mevcuttur."

Kadınlara özel katlar ve/veya oteller konseptinin ağırlıklı olarak iş seyahatine çıkan kadınlara yönelik olduğu ve konseptin varlığının büyük ölçüde arz talep ilişkisi ile şekillendiği anlaşılmaktadır. Otellerde bu konsepte yer verilmesi temelde iki ana değişkenle ilgilidir. Bunlardan ilki, kadınların seyahatleri sırasında kendilerini güvende hissetmeleri diğeri ise kendilerini özel hissetmeleridir. Kişisel tercihe bağlı olarak gelişen bu konseptin ayrımcılık temeline dayanmadığı anlaşılmaktadır. Çünkü kadınlar istedikleri katta kalabilmekte ve istedikleri odayı seçebilmektedirler. Ayrıca kadınlara yönelik ayrımcılık konusundaki farkındalık çalışmalarının dünyanın her yerinde artığı bir dönemde konsepte olan talebin artması ayrımcılık yaklaşımlarını büyük ölçüde ortadan kaldırmaktadır. Eğer bir ayrımcılık göstergesi olarak gerçekleştiriliyor olsaydı, bu ayrımcılığa maruz kalan kadınlar tarafından her geçen gün bu oteller daha fazla sayıda tercih edilmezlerdi. Otellerden alınan dönütlere bakıldığında genellikle bu konseptin otelin doluluk oranını olumlu yönde etkilediği ve tercih edildiğini göstermektedir. Bunun yanı sıra memnuniyet düzeyinin iyi olduğu ve konseptin tercih edenler tarafından eleştiri almadığı da gözlemlenmiştir.

\section{TURIZM İŞLETMELERI YÖNETICILLERİ, MEDYA VE DİĞER TARAFLARIN KADINLARA ÖZEL KATLAR KONUSUNA BAKIŞI}

Kadınlara özel katlar konsepti ile ilgili olarak ülkeden ülkeye, bölgeden bölgeye, toplumdan topluma ve hatta kişiden kişiye değişen görüş farklılıkları bulunmaktadır. Kimileri otellerin kadın - erkek ayrımcılık yaptığını düşünürken kimileri ise bunun iyi bir pazarlama taktiği olduğunu, seyahat eden kadınlar için iyi bir 
imkan olduğunu dile getirmektedir. Örneğin, Wanderlust and Lipstick.com'un kurucusu Beth Whitman'a göre "kadınlara özel otel katlarına sahip olmak mükemmel bir fikir, iş veya eğlence için yalnız seyahat eden kadınlar için güvenli bir ortam sağlamaktadır" (cntraveler.com).

"Erkekler giremez" sloganiyla kadınlara özel otel konseptine yer veren Generator hostel genellikle yalnız dolaşan genç kadınlardan talep gördüklerini belirtmektedir. Rezarvasyon müdürü Esther Amatriain "kadınlar tarafından tercih edilme nedenlerini, kadınların kendilerini güvende hissetmeleri olarak açılamaktadır. Bu konseptte başlangıçta 6 oda olduğunu söyleyen Amatriain talepteki artış nedeniyle 4 oda daha eklediklerini belirtmiştir (broadly.vice.com).

Dukes Hotel'in genel müdürü Debrah Dhugga otellerinde kadınlara özel katlar bulunmasının nedenini, " nerede olursa olsun kadınlarında tıpkı erkekler gibi kendilerini rahat hissetmelerini istiyorum" şeklinde açıklamış ve şuan için bu hizmetten yararlanan kadınların çoğunluğunun iş kadınlarından oluştuğunu ifade etmiştir. Debrah, tüm yaş grubundaki kadınların ve gezgin kadınların da dahil olması gereken geniş bir ağın kurulması gerektiğini de ısrarla vurgulamıştır (broadly.vice.com).

Smartertravel yazarı Srah Schlichter'e göre "kadınlara yönelik oluşturulan bu alanların güvenli olması ve kadınların kişisel tercihlerine saygı duyulmasını kadın dostu bir olay olarak görüyorum ve nihayetinde kadınlara değer verildiğine inanıyorum. Ayrıca bunları talep eden kadınlar için seçenekler bulunmasından da memnuniyet duyduğumu ifade etmek istiyorum" şeklinde bir demeç vermiştir (smartertravel.com). Crowne Plaza Milwaukee yetkililerine göre ise bu bir izolasyon anlamına gelmektedir ve birçok seyahat eden kadın bunu talep etmektedir (Finney, 2008). Virgin Otelin sahibi Branson'a göre ise seyahat eden kadın gezginlere odaklanılması akıllıca bir yöntem ve bu yönde eğilimler git gide artmaya başlamıştır. $\mathrm{Bu}$ nedenle hem güvenli hem de kadın gezginler için tasarlanmış odalara otelinde yer vermiş ve kadınlara özel odalar ve katlar konusunun yukarı yönlü bir eğilim içerisinde olduğunu belirtmiştir (broadly.vice.com).

Times Square' de bulunan Premier Otelin pazarlama müdürü Maureen O'Brien "İş kadınlarının çok çalıştığını dolaysısıyla, az olan boş zamanlarını büyük bir küvette dergi okuyarak geçirmeye hakları olduğunu ifade etmektedir. Crowne Plazadan bir yetkili, kadın dostu katların otelin diğer katlarına olan taleple aynı ölçüde pazarlandığını ifade etmiştir. Yukarıda da ifade edildiği gibi söz konusu otel veya katlarda güvenlik en önemli argümandır. Zira otel odası ürünlerini pazarlayan ve her gün bir başka otelde konaklamak durumunda olan 55 yaşındaki Babara Atkinson, Washington DC'ye verdiği demeçte Crowne Plazada bulunan kadınlara özel katta konakladığını ve güvenliğin üst düzeyde olması nedeniyle kendini daha huzurlu hissettiğini ifade etmiştir (forbes.com). USA Today Road Warrior'un satıştan sorumlu başkan yardımcısı Stephanie Dickey dünyanın farklı kentlerinde kadın gezginlere ayrılmış otellerin olmasından oldukça memnun olduğunu ve bunun kendisini özel hissettirdiğini söylemiştir (usatoday.com). Michigan Üniversitesinden Gerald Ford, 
kamu politikası okulunda kadın araştırmaları profesörü olan Mary Corcoran'a, kadınlara özel katlar düşüncesinin yalnız kalmak isteyen kadınlar için eşsiz bir fırsat olduğunu ifade etmiş ve daha önce bu fikri duymadığını belirten Mary'ye özellikle yabancı yerlere yapılan seyahatlerde bu katların varlığı kadınların seyahat kararı almalarını cesaretlendirci bir faktör olarak öne çıktığını söylemiştir (www.ozy.com).

Ancak kadınların beklentilerini karşılayan bu otellere olumlu yaklaşanların yanı sıra verilen hizmetin bir çeşit ayrımcılık olduğunu (Kophenag da bu konuyla ilgili bir yasal düzenleme var) düşünenlerde bulunmaktadır. Karşı düşüncelerin bir kısmı nihayetinde bu uygulamanın kadınlar açısından bir seyahat deneyimi olduğu ve bu yaklaşımla kendilerini gerçekleştirme şansı bulduklarını da eklemektedirler (ellgeebe.com). Bunun yanında Big idea kitabının yazarı Donny Deutsch gibi kişiler ise tarafların bu durumdan memnun olduğunu ve bu konseptin harika bir fikir olduğunu ifade etmişlerdir. Ayrıca kadın müşterilerine yardımcı olmanın ve kadınların ihtiyaçlarını karşılamanın misafirperverlik olduğunu ifade eden Deutsch bu uygulamada yanlış olan nedir şeklinde bir de soru yöneltmiştir (today.com). Dahası bu uygulamanın giderek yagınlaştığı bilgisine de yer vermiştir. Zira Euromonitor İnternational'in seyahat ve turizm araştırmacıları yöneticisi Michelle Grant söz konusu otellerin sunduğu kadın katlarında bir artış olduğunu ve bu artışın düzenli bir şekilde gerçekleştiğini dile getirmiştir (hotelnewsnow.com).

Kadınlara özel otel veya katlar ile ilgili tartışmalar yalnızca ayrımcılık üzerinden değil aynı zamanda otellerin müşterilerine sundukları hizmetler üzerinden de yapılmaktadır. Örneğin Hawai ve California merkezli uçuşları yöneten Jennifer Welchikirpik, kıvırılan yaylı demir, yoga matı ve benzeri aksesuarların söz konusu otellerde olmasının kendisi açısından memnuniyet verici olduğunu ancak her kadının bu tarz malzemelere farklı bakacağını hatta cinsiyet ayrımcılığı olarak dahi göre bileceklerini ifade etmektedir (usatoday.com).

Öyle görülüyor ki, kadınlara özel katlar konseptinin bir ayrımcılık mı yoksa başarılı bir iş mi sorusuna bundan sonra da cevap aranacak. Bu anlamda Los Angeles'ta avukat olan Gloria Allred bu durumun bir ayrımcılık olduğunu ifade etmiştir. Ve ifadesini şu şekilde devam ettirmiştir. Kadınlara ayrılan koridorlarda erkeklerin hariç tutulması ve eskiden olduğu gibi sadece erkeklere özel salonlar oluşturulmamasının hiç de adil olmadığını savunmuştur. Zira Allred'a göre kadınların istediği, sadece eşit haklar ne daha fazla ne de da daha az haklar değil, eşit haklardır (today.com). Seyahat acentası sahibi Meg Ryan ise kadınlara özel katlar ile ilgili görüşünü şu şekilde ifade etmiştir. Hayır almayayım teşekkürler! Dahil olan herhangi bir süslemeyle birlikte kadınların tek katına ihtiyacım yok (travelupdate.boardingarea.com). Deniz kuvvetlerinde emekli pilot olan Elizabeth Toedt ise bu konsepti ilginç ve hakaret edici bulduğunu ifade etmiş ve kadınların yıllarca eşit muamele görmek için verdiği mücadelenin sonunda ortaya çıkan bu manastır tipi otelleri geriye doğru bir adım olarak nitelendirmiştir (usatoday.com). Esas olarak kadınlara yönelik bu uygulamaların yeni olmadığ geçmişte de benzer otel uygulamaların var olduğuna işaret eden kişiler de bulunmaktadır. Bunlardan biri olan JWT'de pazarlama iletişim firması trend tespiti yapan Ann Mack "bu uygulamalar bir 
zamanlar cinsiyetçi olarak işten çıkartılan ve çoğunlukla ticaretle uğraşan kadın yolcuların bir sonucu olarak ortaya çıkan eski bir kavram" olduğunu ifade etmiştir (intransit.blogs.nytimes.com).

Yukarıda görüldüğü üzere literatürde çok sayıda olumlu veya olumsuz görüşe ulaşabilmek mümkün. Bu trendin iyi bir fikir olmadığın savunanlar genellikle bu durumu ayrımcılık temelinde ele alırlarken, iyi bir fikir olduğuna savunanlar ise uygulamanın iyi bir pazarlama çalışması, arz talep arasındaki ilişki, kadınların artan seyahatleri ve güvenlik endişeleri temelinde ele almaktadırlar. Bununla birlikte söz konusu uygulamanın oldukça yeni sayıldığını ve zamanla farklı yaklaşım ve tartışmaların gelişebileceğini de söylemek mümkündür. Zira kadın katları konusu, 2010 yılından bu yana yalnızca kadın gezginlerin talep ettikleri güvenlik kaygıları üzerine New York, Londra, Berlin ve Toronto gibi büyük şehirlerde trend haline gelen bir uygulamadır (Arabnews.com). Büyük kentlerde bu uygulamanın ilk örneklerinin görülmesi tamamıyla kadın gezginlerin bir şekilde maruz kaldıkları güvenlik endişeleriyle ilgili olduğunu söylemek yanlış olmasa gerek. Dahası söz konusu kentler ve dünyanın farklı bölgelerinde bulunan benzer kentlerin tamamında yalnızca kadınlar değil erkeklerin de zaman zaman güvenlik endişesi yaşadığı bilinmektedir. Dolayısıyla yalnız başına seyahat eden kadınların endişe duyması anlaşılır bir durumdur. Var olan bu durum ayrımcılıktan ziyade hayatın bir gerçeği olarak görülmeli ve konaklama işletmelerinin bunu fırsata çevirdiği unutulmamalıdır.

\section{SONUÇ}

Kadınlara özel katlar konsepti konaklama işletmeleri için yeni bir niş pazar niteliğindedir. Bu pazarı yeni bir iş fırsatı olarak değerlendiren işletmelerin sayısı her geçen gün artmaktadır. Bu artış pazarlamada önemli bir faktör olan cinsiyet konusunun temel belirleyici değişkenler arasında yer almasına neden olmuş ve dolayısıyla konaklama işletmeleri ortaya çıkan bu durumu fırsata çevirmişlerdir.

Kadınların her geçen gün daha fazla seyahat etme isteği, sosyal alanda etkin rol almaları, karar verici konumlarda bulunmaları, çalışma hayatında giderek daha aktif yer almaları, kadın haklarında yaşanan kazanımlar (ilerleme) ve benzeri gelişmeler birçok sektörün kadınlara yönelik yeni yaklaşımlar geliştirmelerine neden olduğu gibi konaklama işletmelerini de kadınlar için daha özel hizmetler sunma yönünde teşvik etmiştir.

Geçmişte kadının sadece ev hayatında var olması ve belli kalıplara sokulması kadınları ayrıştırıcı temele dayalı bir sürecin parçası haline getirmişken, bugün yaşanan zihinsel kırılma ve elde edilen kazanımlar kadınların başka bir gözle değerlendirilmesine neden olmuş ve bu durum diğer birçok sektörde olduğu gibi konaklama sektöründe de bir tüketici olarak kadının farklı açılardan değerlendirilmelerine yol açmıştır. Konaklama işletmelerinde kadınlara olan bu özel ilgi kadınların toplumda artık dışlanan değil önemsenen birer birey olduklarının kanitidir. 
Kadınların seyahatleri sırasında güvenli konaklamalarını sağlamak, kendilerini özel ve rahat hissettirecek hizmetler sunmak, yeni deneyimler yaşamalarına fırsat vermek kadınlara özel katlar konseptinin belirleyici özelliklerindendir. Kadın gezginin kendisini iyi hissettirmesi adına gerçekleştirilen bu konsept herhangi bir ayrımcilık fikrine dayanmamaktadır. Zira bu odaların seçimi tamamen kadınların iradesiyle ilgili ve bireysel tercihlerinin sonucudur.

Her ne kadar ayrımcılığı çağrıştırsa da bu durum esasında bir ayrımcılık değil, özgür seyahat etme konusunda bir kolaylıktır. Kabul edilse de, edilmese de kadınlara yönelik nefret suçları dünyanın birçok ülkesinde artış eğilimindedir. Bir taciz veya tecavüzle ne zaman karşılaşacağını bilemeyen bir kadın bildiği ya da bilmediği bir yere seyahat ederken her zaman endişelidir. Bütün bu endişelere son vermek için gerçekleştirilen bu küçük jest bir ayrımcllı unsuru olarak görülmemelidir. Esas ayrımcılık bir kadının seyahat etme özgürlüğünü kısıtlayan nefret suçlarıdır. Bunun önüne geçebilme fırsatını kadınlara veren bu konsept hem ülkemiz hem de diğer ülkeler için bir alternatif hizmet oluşturabilir.

Konaklama işletmelerinde kadın odaklı niş pazarlama gerçekleştirmek kadınların turizme olan bakış açısını değiştirecektir. Kendisine özel olarak hazırlanmış ve güvenli bir odada konaklayan bir kadın bir sonraki seyahatini daha huzur içinde gerçekleştirecektir. Ayrıca bu konseptlerin varlığı oteli veya şehri güvenlik sorunu olan bir yer haline getirmez, bu, sadece özgür iradeye dayalı bir alternatif olarak misafir memnuniyeti için gerçekleştirilen bir jest olarak düşünülmelidir.

Turizm sektöründe bu tür bir niş pazarın var olduğu görülmektedir ve bu pazar her geçen gün genişlemektedir. Araştırmaya katılan otellerin söylemlerine göre bu otel odalarına olan talep oldukça yüksektir. Bu anlamda bu konsepti Türkiye'de uygulamak bu otellere yönelik bir talep artışına neden olabilir. Örneğin İstanbul'u 2017 yılı boyunca 10.840.595 yabancı turist ziyaret etmiştir (istanbulkulturturizm.gov.tr). Bu yabancı turistlerin içerisinde Türkiye'yi ilk defa ziyaret eden kadın turistlerin de bulunduğu göz önüne alındığında İstanbul'daki otellerin bu konsepte yer vermeleri otellere olan ilgiyi arttırabilir. Sonuç olarak kadınlara özel katlar konsepti kadınların daha özgür, daha rahat, daha güvenli bir seyahat gerçekleştirmeleri için bir alternatif sunabilir.

\section{KAYNAKÇA}

Aksu, M., Aktaş, A. R., Oku, O., Şentürk, F.K., (2013) Yabancı Turistlerin Güvenlik Algılarının Analizi:Alanya Örneği. International Conference On Eurasian Economies

Albar, Ö. B., Duman, T., (2011)Bir Tüketici Grubu Olarak Kadınların Mağaza Markalı Ürünlere Karşı Tutumları :Giresun İli Örneği. Erciyes Üniversitesi İktisadi ve İdari Bilimler Fakültesi (38)

Bakırtaş, H., (2013) Tüketicilerin satın alma kararı üzerinde satış tutundurmanın etkisi: Turizm sektöründe bir uygulama. International Journal of Human Sciences, 10 (1)

Bulut, Y., (2011) Otellerde Müssteri Memnuniyeti Bir Uygulama (Samsun Örneği). Uluslararası Sosyal Araştırmalar Dergisi, 4 (18): 394 
Çakır, B. D., (2010) Avrupa Birliği ve Türk Hukukunda Çalışma Yaşamında Kadın-Erkek Eşitliği. Trabzon: Karadeniz Teknik Üniversitesi Uluslararası İlişkiler Fakültesi

Finney, P. B., (2008) Female-Friendly Hotels. New York Times

Gordon, M. and Riger, S. (1989) The Female Fear. New York: The Free Press

Gönüllü, M., İçli, G., (2001) Çalışma Yaşamında Kadınlar: Aile ve İş İlişkileri. C.Ü. Sosyal Bilimler Dergisi, 25 (1): 82

Göl, N. (2010) Türkiye'de Kadın Hareketine KA-DER (Kadın Adayları Destekleme ve Eğitme Derneği) Bağlamında Bir Bakış

Harman, S., (2014) Bağımsız Seyahat Eden Yerli Gezginlerin Seyahat Motivasyınları Üzerine Bir Araştırma. Uluslararası Yönetim ve İşletme Dergisi, 10 (21)

Kılıçer, T., Boyraz, E., Tüzemen, A., (2016) Kadın, Erkek, Ya Da Hediye Satın Alma Davranışında Cinsiyet Kimliği Rolünün Etkisi. Ege Akademik Bakış 16 (1): 122

Koca, E., Çağman, D. S., (2012)Kullanılmayan Giysilerin Değerlendirilmesinde Çalışan Kadınların Ekolojik Yaklaşımları. Selçuk Üniversitesi Sosyal Bilimler Enstitüsü , (27)

Karaslan, U., (2015) 19. Yüzyılda Batı'da Kadın Hakları Hareketinin Tarihsel Gelişimi. Kocaeli: Kocaeli Üniversitesi Hukuk Fakültesi.

Loukaitou-Sideris, A., (2014) Fear and safety in transit environments from the women's perspective. Security Journal, 27 (2)

Minnaert,L.(2007) A proposed teaching plan for exploring cultural attitudes towards womenonly hotel floors. The Times

Özdemir, E., Tokol, T. (2008) Kadın Tüketicilere Yönelik Pazarlama Stratejileri. Anadolu Üniversitesi Sosyal Bilimler Dergisi, 8(2): 57

Tekvar, S. O., (2016) Tüketici Davranışlarının Demografik Özelliklere Göre Tanımlanması. İnsan ve Toplum Bilimleri Araştırmaları Dergisi, 5 (6): 1603

Swengley, N., (2003) Hotels learn to be female-friendly.Times, The (United Kingdom)

Yayla, K., (2010) Simone De Beauvoır'ın Feminizm Perspektifi.İstanbul:Galatasaray Üniversitesi Hukuk Fakültesi.

Yang, E. C. L., Khoo-Lattimore, C., Arcodia, C., (2016) A narrative review of Asian female travellers:looking into the future through the past. Current Issues in Tourism, 20 (3)

\section{İnternet Kaynakçası}

https://www.usatoday.com/story/travel/hotels/2013/12/08/hotels-women-only-floors/3910931/

[23.01.2018]

https://www.smartertravel.com/2017/06/19/female-accommodations-women-want/ [23.01.2018]

https://www.tripadvisor.com/LocationPhotoDirectLink-g60795-d96698-i75105574-

Crowne_Plaza_Philadelphia_West Philadelphia_Pennsylvania.html[23.01.2018]

http://www.ellishotel.com/womens-floor-en.html[23.01.2018]

http://www.arabnews.com/news/453803 [31.01.2018]

https://www.tripadvisor.com/LocationPhotoDirectLink-g189541-d1986559-i88470883-

AC_Hotel_by_Marriott_Bella_Sky_Copenhagen-Copenhagen_Zealand.html [23.01.2018] 
https://www.dukeshotel.com/duchess-rooms/[23.01.2018]

http://www.bwcityhotel-ge.it/en/services/woman-package.aspx[23.01.2018]

https://generatorhostels.com/ [23.01.2018]

https://www.orsamaggioreroma.com/en/ [23.01.2018]

https://www.smartertravel.com/2014/09/04/no-boys-allowed-hotels-with-women-only-floors/ [23.01.2018]

https://www.itchotels.in/accommodation/eva-rooms.html[23.01.2018]

https://www.makemytrip.com/blog/safe-hotels-in-india-for-women-travellers [23.01.2018]

https://www.tajhotels.com/en-in/womens-vacations/ [23.01.2018]

https://www.makemytrip.com/blog/safe-hotels-in-india-for-women-travellers [23.01.2018]

http://www.theimperialindia.com/eliza-room/[23.01.2018]

https://www.off-to-on.com/en/report/capsule-hotel/all\%20area/capsulehotel-lady? [23.01.2018]

http://nadeshiko-hotel.jp/ [23.01.2018]

http://hongkongbusiness.hk/hotels-tourism/life-style/first-in-hong-kong-fleming-featurescustomized-room-women [23.01.2018]

http://www.luthanhotel-spa.com/ [23.01.2018]

https://www.jumeirah.com/en/hotels-resorts/dubai/jumeirah-emirates-towers/rooms-andsuites/chopard-ladies-room/[23.01.2018]

http://www.dailymail.co.uk/femail/article-2521610/The-women-hotel-floors-added-securityroom-yoga-mats.html [24.01.2018]

https://www.ladysfirst.ch/ [24.01.2018]

https://www.sekkamag.com/article/why-women-only-hotel-floors-are-on-the-rise [24.01.2018]

http://www.lottehotel.com/seoul/en/accom/accommo.asp?roomTypeCd=LD [24.01.2018]

https://www.forbes.com/2009/02/04/vacation-business-trip-women-

travel_0205_hotel.html\#1d6fda156434 [24.01.2018]

https://www.cntraveler.com/stories/2013-12-12/women-only-hotel-floors-are-insulting-but-notfor-the-reason-you-think [24.01.2018]

https://broadly.vice.com/en_us/article/wnwven/how-hotels-are-capitalizing-on-womens-fearsof-traveling-alone [15.11.2017]

http://www.ozy.com/immodest-proposal/hotels-should-create-women-only-floors/41448

[15.11.2017]

https://www.ellgeebe.com/en/collections/hotels-with-women-only-floors [16.11.2017]

https://www.today.com/news/early-halloween-decoration-so-scary-police-get-flooded-911calls-t116627 [15.11.2017]

http://travelupdate.boardingarea.com/womens-hotel-floors-enough-already/ [15.11.2017]

http://www.hotelnewsnow.com/Articles/16839/Women-only-floors-cater-to-growing-market [10.11.2017] 
F. Alaeddinoğlu, A. Ayhan / Karabük Üniversitesi Sosyal Bilimler Enstitüsü Dergisi, 2018, 8 (2), 515-536

https://intransit.blogs.nytimes.com/2012/01/29/hotels-create-rooms-and-floors-just-forwomen/?mcubz $=0 \&$ mcubz $=0$ [10.11.2017]

https://edition.cnn.com/2012/03/07/business/women-hotels-business-travelers/index.html [31.01.2018]

http://gulfnews.com/leisure/travel/rising-demand-for-women-only-floors-in-hotels-1.998745 [31.01.2018]

https://www.fourseasons.com/riyadh/accommodations/the_pearl_floor/ [31.01.2018]

http://www.georgiancourthotelvancouver.com/hotel-rooms/orchid-floor/ [31.01.2018]

http://www.istanbulkulturturizm.gov.tr/Eklenti/56803,aralik-2017pdf.pdf?0 [08.02.2018] 


\section{EKLER:}

Tablo 1. Kıtalar İtibariyle Kadınlara Özel Katlar Bulunan Oteller

\begin{tabular}{|c|c|c|}
\hline AMERIKKA & ASYA & Japonya Otelleri \\
\hline $\begin{array}{l}\text { - Georgian Court Hotel, } \\
\text { Vancouver-kanada } \\
\text { - Hamilton Crowne Plaza, } \\
\text { Washington-Amerika } \\
\text { - Crowne Plaza } \\
\text { Bloomington, } \\
\text { Minneapolis-Amerika } \\
\text { (usatoday.com) } \\
\text { - Ellis Hotel, Atlanta- } \\
\text { Amerika (ellishotel.com) } \\
\text { - Crowne Plaza } \\
\text { Philadelphia West, } \\
\text { Philadelphia-Amerika } \\
\text { (tripadvisor.com) }\end{array}$ & $\begin{array}{l}\text { - Taj Dubai, Dubai } \\
\text { - Vivanta by Taj Bentota, } \\
\text { Srilanka } \\
\text { - The Fleming Hotel, Hongkong } \\
\text { (hongkongbusiness.hk) } \\
\text { - Luthan Hotel and Spa, } \\
\text { Riyadh-Suudi Arabistan } \\
\text { (luthanhotel-spa.com) } \\
\text { - Jumeriah Hotel, Dubai } \\
\text { (jumeirah.com) } \\
\text { - Lotte Hotel, Kore } \\
\text { (lottehotel.com) }\end{array}$ & $\begin{array}{l}\text { - Green Plaza Shinjuku Capsule } \\
\text { Hotel, Chiba-Japonya } \\
\text { - Capsule Inn Kinshicho, Chiba- } \\
\text { Japonya } \\
\text { - Oak Hostel Cabin, Tokyo-Japonya } \\
\text { - Centurion Cabin\&Spa, Tokyo- } \\
\text { Japonya } \\
\text { - First Cabin Atagoyama, Tokyo- } \\
\text { Japonya } \\
\text { - First Cabin Tsukiji, Tokyo- } \\
\text { Japonya } \\
\text { - Tokyo Ginza Bay Hotel, Tokyo- } \\
\text { Japonya } \\
\text { - First İnn Kyobashi, Tokyo- }\end{array}$ \\
\hline AVRUPA & Hindistan Otelleri & \\
\hline $\begin{array}{l}\text { - AC Hotel by Marriott } \\
\text { Bella Sky Copenhagen, } \\
\text { Danimarka } \\
\text { (tripadvisor.com) } \\
\text { - Dukes Hotel, Londra } \\
\text { (dukeshotel.com) } \\
\text { - Best Western Plus City } \\
\text { Hotel, İtalya } \\
\text { (bwcityhotel-ge.it) } \\
\text { Genarator Hostels } \\
\text { Amsterdam, Barselona, } \\
\text { Berlin, Dublin, } \\
\text { Hamburg, Madrid, Paris, } \\
\text { Roma, Kopenhag, } \\
\text { Stokholm, Londra, } \\
\text { Venedik } \\
\text { (generatorhostels) } \\
\text { Lady's First Design } \\
\text { Hotel, Zürih } \\
\text { (ladysfirst.ch) }\end{array}$ & $\begin{array}{l}\text { - ITC Grand Chola, Chennai } \\
\text { - ITC Maratha, Mumbai } \\
\text { - ITC Maurya, New Delhi } \\
\text { - ITC Gardenia, Bengaluru } \\
\text { - ITC Windsor, Bengaluru } \\
\text { - ITC Grand Central, Mumbai } \\
\text { (itchotels.in) } \\
\text { - Lemon Tree } \\
\text { Premier/Hyderabad } \\
\text { - Lemon Tree } \\
\text { Hotel/Chandigarh } \\
\text { - Lemon Tree Hotel/Gurgaon } \\
\text { (makemytrip.com) } \\
\text { - The Oberoi Amarvilas, Agra } \\
\text { - The Oberoi, Gurgaon } \\
\text { - The Oberoi, Bengaluru } \\
\text { - The Oberoi, Mumbai } \\
\text { (makemytrip.com) } \\
\text { - Vivanta by Taj Holiday } \\
\text { Village, Goa } \\
\text { - Vivanta by Taj Fort Aguada, } \\
\text { Goa } \\
\text { - Vivanta by Taj Green Cove, } \\
\text { Kovalam } \\
\text { - Vivanta by Taj Fisherman's } \\
\text { Cove, Chennai } \\
\text { - The Gateway Hotel Ganges, } \\
\text { Varanasi (tajhotels.com) } \\
\text { Hindistan } \\
\text { (theimperialindia.com) } \\
\text { - Taj Nadesar Palace, Varanasi }\end{array}$ & $\begin{array}{l}\text { - On The Marks Kawasaki, } \\
\text { Kanagawa-Japonya } \\
\text { - Capsule Hotel Asahi Plaza } \\
\text { Shinsaibashi, Osaka-Japonya } \\
\text { - Capsule Hotel B\&S Eco Cube, } \\
\text { Osaka-Japonya } \\
\text { - Grand Sauna Shinsaibashi, } \\
\text { Osaka-Japonya } \\
\text { - B\&CHotel Sun Play Inn } \\
\text { Nagahori, Osaka-Japonya } \\
\text { - First Cabin Midosuji Namba, } \\
\text { Osaka-Japonya } \\
\text { - Sauna\&Capsule Spadio-Japonya } \\
\text { - First Cabin Kyoto Karasuma, } \\
\text { Kyoto-Japonya } \\
\text { - Nine Hours Kyoto, Kyoto- } \\
\text { Japonya } \\
\text { - Kobe Kua House, Hyogo-Japonya } \\
\text { - Capsule Hotel Cube, Hiroshima- } \\
\text { Japonya } \\
\text { - First Cabin Hakata, Fukuoka- } \\
\text { Japonya } \\
\text { - Star Capsule, Okinawa-Japonya } \\
\text { - Noff-to-on.com) } \\
\text { Jadeshiko Capsule Hotel- } \\
\text { Japonya (nadeshiko-hotel.jp) } \\
\text { - Saponya Hours Sendai, Miyagi- } \\
\text { Hotel, Chiba-Japonya } \\
\text { - Nine Hours Narita, Chiba- } \\
\text { Jaku Kuyakushomae Capsule }\end{array}$ \\
\hline
\end{tabular}


Tablo 2. Kadınlara Özel Katlar Konsepti Bulunan Oteller ve Sundukları Hizmetler (Özellikleri)

\begin{tabular}{|c|c|}
\hline Otel Adı & - Hizmetler (Özellikleri) \\
\hline $\begin{array}{l}\text { Dukes Hotel } \\
\text { İş ve eğlence amaçlı seyahat eden } \\
\text { kadınlar için düşes odaları } \\
\text { tasarlamıştır. }\end{array}$ & $\begin{array}{l}\text { - Kadınlara eşlik etme, oda servisi ve oda temizliği hizmetlerini } \\
\text { yerine getirmek için kadın çalışanlar, } \\
\text { - Taze çiçekler ve ücretsiz bir meyve tabağı mevcuttur, } \\
\text { - Makyaj aynası, saç kurutma makinesi ve aksesuarlar, giyinilecek } \\
\text { yere ve kolay ulaşılabilir bir noktaya bırakılmaktadır, } \\
\text { - Her odada parlak yaşam tarzı dergileri ve küçük boyutlu } \\
\text { terlikler bulundurulur (dukeshotel.com). }\end{array}$ \\
\hline $\begin{array}{l}\text { Ellis Hotel } \\
\text { Atlanta'da bulunan Ellis Hotel } 10 . \\
\text { katını kadınlara özel bir kat olarak } \\
\text { dizayn etmiştir. Odalara özel bir } \\
\text { erişim sunan bir asansörle } \\
\text { çıkılmaktadır }\end{array}$ & $\begin{array}{l}\text { - Hediye olarak şampuan, saç kremi, duş jeli, losyon, yüz } \\
\text { temizleme toniği, törpü içeren L'Occitane kozmetik çantası, } \\
\text { - Chelko Vakfı ile ortaklık nedeniyle ünlü tablo "Chelko Kalp"'ın } \\
\text { minyatür kopyası } \\
\text { - Kat'a çıkan asansörde, parlak sarı çiçekler ve hafif çiçek aroması } \\
\text { misafirleri karşılıyor, } \\
\text { - Otel'in } 10 \text { odasında, kadınların güzelliğinin özünü gösteren } \\
\text { Chelko Vakfı baskısı bulunuyor. } \\
\text { - Her odada rahat terlikler, pelüş bornozlar, Gilchrist\&Soames } \\
\text { tuvalet malzemeleri, mineral jöleler bulunmaktadır } \\
\text { (ellishotel.com). }\end{array}$ \\
\hline $\begin{array}{l}\text { Four Seasons Hotel Riyadh } \\
\text { Riyadh'a giden kadınların rahat ve } \\
\text { güvende hissetmelerine yardımcı } \\
\text { olmak amacıyla } 20 \text { Premium ve } \\
\text { Deluxe Oda ile iki Four Seasons } \\
\text { Executive Suitten oluşan The Pearl } \\
\text { Floor tasarlanmıştır }\end{array}$ & $\begin{array}{l}\text { - Deneyimli kadın personel ekibinden yönetilen, kadınların } \\
\text { konaklamasını kolaylaştırmak adına kişiye özel ve güvenilir } \\
\text { hizmet vermek için özel ekspres chek-in bürosu } \\
\text { - Sicak bir ev hissi veren zarif dokunuşlarla dekore edilmiş Riyad } \\
\text { manzaralı oda ve süitler, } \\
\text { - Kişiye özel oda kokuları } \\
\text { - Riyad manzaralı zengin Pearl Floor lobisi } \\
\text { - Kadın dergileri } \\
\text { - Yoga matı } \\
\text { - Lüks yüz ve vücut bakım ürünleri, } \\
\text { - Profesyonel saç kurutma makinesi seti } \\
\text { - Özenle seçilmiş nevresim ve yorganlar } \\
\text { - Konukların ücretsiz Wi-Fi'ye ve ücretsiz ikramlara yer verilen } \\
\text { seçkin ve son teknolojiyle donatılmış spor salonu yer almaktadır } \\
\text { (fourseasons.com). }\end{array}$ \\
\hline $\begin{array}{l}\text { Genarator Hostel } \\
\text { Amsterdam, Barselona, Berlin, } \\
\text { Dublin, Hamburg, Madrid, Paris, } \\
\text { Roma, Miami, Kopenhag, Stokholm, } \\
\text { Londra, Venedik gibi birçok şehirde } \\
\text { bulunan bir zincir hosteldir. } \\
\text { Hostellerin hepsinde yalnızca } \\
\text { kadınların paylaşabileceği ve } \\
\text { "Erkekler giremez! burası sadece } \\
\text { kızların" sloganı ile oluşturulan } \\
\text { odalar bulunmaktadır. }\end{array}$ & $\begin{array}{l}\text { - Kadınlara özel banyo malzemeleri } \\
\text { Daha ayrıntılı saç kurutma makinesi, boy aynası, bibi ekstra } \\
\text { eşyalar bulunmakta, } \\
\text { 1-6 kişi konaklayabilmektedir (generatorhostels.com). }\end{array}$ \\
\hline
\end{tabular}




\begin{tabular}{|c|c|}
\hline Otel Adı & - Hizmetler (Özellikleri) \\
\hline $\begin{array}{l}\text { Georgian Court Hotel } \\
\text { Kanada'nın Vancouver şehrinde } \\
\text { bulunan ve kadın gezginlere özel } 18 \\
\text { odasıyla hizmet veren Georgian } \\
\text { Court Hotel'de, "Orchid Floor" kat'1 } \\
\text { bulunmaktadır. }\end{array}$ & $\begin{array}{l}\text { - Ek bir ücret alınmaz } \\
\text { - Kadınlara özel banyo aksesuarları } \\
\text { - Yalnızca kadınlara özel acil durum araç gereçleri } \\
\text { - Kadınlara özel yoga matları } \\
\text { - Saten etek askıları } \\
\text { - Stil ve moda dergileri } \\
\text { - Bavul ve ayakkabılar için daha geniş bir alan yer almaktadır } \\
\text { (georgiancourthotelvancouver.com). }\end{array}$ \\
\hline $\begin{array}{l}\text { Jumeirah Emirates Towers } \\
\text { Dubai'de bulunan Jumeirah Emirates } \\
\text { Towers'da kendisini daha sofistike ve } \\
\text { özel hissetmek isteyen kadın } \\
\text { gezginler için "Chopard Ladies' } \\
\text { Floor" bulunmaktadır. }\end{array}$ & $\begin{array}{l}\text { - Güzel çiçek derlemeleri, } \\
\text { - Lüks Chopard banyo ürünleri ve pièce de résistance, } \\
\text { - Özel makyaj dolabı, } \\
\text { - Yoga olanakları, bornoz ve kimono, } \\
\text { - Kadın çalışanlar, } \\
\text { - Kadınlar için özel nevresim ve yorganlar yer almaktadır } \\
\text { jumeirah.com). }\end{array}$ \\
\hline $\begin{array}{l}\text { Luthan Otel ve Spa } \\
\text { Suudi Arabistan'da bulunan Luthan } \\
\text { Otel ve Spa Ortadoğu'da kadınlara } \\
\text { özel otel konseptinin ilk } \\
\text { örneklerindendir. İş veya gezi amaçlı } \\
\text { seyahat eden kadın gezginlerin tercih } \\
\text { ettiği bir oteldir. }\end{array}$ & $\begin{array}{l}\text { - Spa'nın özünü anlamak için özel olarak hazırlanmış odalar } \\
\text { - Aqua Meditasyon Odası, Refleksoloji havuzu, Ses havuzu, } \\
\text { Cysternae, Tuz Inhalasyon Odası, Bitkisel Sauna, Buz Çeşmesi } \\
\text { havuzu, Dinlenme Odası, Kapalı ısıtmalı yüzme havuzu, jakuzi } \\
\text { ve Baleno ses havuzu } \\
\text { - Hem kozmetik hem de fitness odaklı son teknoloji ürünü } \\
\text { ekipmanlar } \\
\text { - Ücretsiz karşılama } \\
\text { - Bornozlar, profesyonel saç kurutma makinesi, ayrı duş ve } \\
\text { küvete sahip banyo } \\
\text {-Bagaj rafı olanakları yer almaktadır (luthanhotel-spa.com). }\end{array}$ \\
\hline $\begin{array}{l}\text { Nadeshiko Hotel Capsule } \\
\text { Birçok kişinin kapsül otellerin } \\
\text { yalnızca erkekler için olduğu } \\
\text { düşüncesinin aksine yalnız başına } \\
\text { seyahat eden çok sayıda kadının } \\
\text { olduğu da bilinmektedir. Bu } \\
\text { bağlamda Tokyo'da bulunan } \\
\text { Nadeshiko Hotel Capsule erkeklere } \\
\text { değil yalnızca kadın müşterilerine } \\
\text { hizmet vermektedir (nadeshiko- } \\
\text { hotel.jp). }\end{array}$ & \\
\hline $\begin{array}{l}\text { The Hamilton Crowne Plaza } \\
\text { Washington D.C'nin merkezinde } \\
\text { bulunan Hamilton Crowne Plaza'nın } \\
\text { 11. katında kadınlara özel konseptli } \\
\text { odalar bulunmaktadır. }\end{array}$ & $\begin{array}{l}\text { - Peluş bornozlar, büyüteç ayna, lüks cilt ve saç bakım ürünleri, } \\
\text { - Kişiselleştirilmiş konsiyerj hizmetleri, } \\
\text { - Kata özel asansör erişimi vardır (hamiltonhoteldc.com). }\end{array}$ \\
\hline $\begin{array}{l}\text { Lotte Hotels } \\
\text { Lotte Hotel, kadınlara özel bir kat } \\
\text { olan "Ladies Floor"u bünyesinde } \\
\text { barındıran Güney Kore'deki ilk } \\
\text { oteldir. }\end{array}$ & $\begin{array}{l}\text { - Kadın konuklar, yeşil veya kırmızı temalı odalar arasında seçim } \\
\text { yapabilirler, } \\
\text { - Dünyaca ünlü çiçekçi Christian Tortu, Fransa, İtalya ve } \\
\text { Portekiz'den gelen mobilya ve eşyalarla dekorasyon, } \\
\text { - Seul'un kuşbakışı görüntüsü, } \\
\text { - En iyi yatak ve yatak takımları, } \\
\text { - } 15 \text { çeşit özel yastık, } \\
\text { Ücretsiz Club Lounge avantajları, yer almaktadır } \\
\text { (lottehotel.com). }\end{array}$ \\
\hline
\end{tabular}

